renal function at the time of diagnosis. ${ }^{4}$ Severe renal failure may develop in some patients, but others improve and no renal dysfunction occurs during follow up.

The reason why some patients are more susceptible to lung than to renal disease is not clear. Inhaled agents may play a part, among them insecticides and herbicides. ${ }^{5}$ The fungicides inhaled by our patient have not been reported to induce anti-basement membrane antibody disease, but cigarette smoking is associated with pulmonary manifestations of the disease. ${ }^{6}$ In animals inhalation of petrol induces lesions in the alveolar basement membrane, allowing circulating anti-basement membrane antibodies to gain access. ${ }^{7}$ Thus increased capillary permeability may be essential for damage to occur. Our patient was a cigarette smoker and was exposed to fumes of fungicides, both of which might have been contributory factors. The unusual susceptibility of a few individuals to widely used exogenous agents suggests a genetically determined background for the development of anti-basement membrane antibody disease. This is supported by the association of the HLA antigen DR2, which our patient possessed, with the disease. ${ }^{38}$

Treatment regimens consist of immunosuppression with or without plasmapheresis. The outcome in patients treated with plasmapheresis is slightly better; but the initial degree of the renal disease is more important for the prognosis than the type of treatment received. ${ }^{9}$ Combined cytotoxic drugs and plasmapheresis also shorten the time needed for clearance of antibodies and improve the outcome in patients with lung haemorrhage and in those not dependent on dialysis. ${ }^{10}$

We are indebted to Professor Dr Meyer zum Bueschenfelde, Klinikum der Johannes Gutenberg Universität, Mainz, Germany, for performing the immunoblot, and to Dr HA Gerber and Mrs E Schnegg, Institute of Pathology, for providing the results of the direct immunofluorescence studies.

1 Goodpasture EW. The significance of certain pulmonary lesions in relation to the etiology of influenza. $\mathrm{Am} \mathrm{J} \mathrm{Med}$ Sci 1919;158:863-70.

2 Lerner RA, Glassock RJ, Dixon FJ. The role of antiglomerular basement membrane antibody in the pathogenesis of human glomerulonephritis. $J$ Exp Med 1967;126:989-1004.

3 Rees AJ, Lockwood CM. Antiglomerular basement membrane antibody-mediated nephritis. In: Schrier RW Gottschalk CW, eds. Diseases of kidney. Boston: Little Brown 1988:2091-125.

4 Mathew TH, Hobbs JB, Kalowski S, Sutherland PW, Kincaid-Smith P. Goodpasture's syndrome: normal renal diagnostic findings. Ann Intern Med 1975;82:215-8.

5 Kleinchnecht D, Morel-Marogar L, Callard P, Adhemar JP, Mathieu P. Antiglomerular basement membrane nephritis after solvent exposure. Arch Intern Med 1980;140:230-2.

6 Donaghy M, Rees AJ. Cigarette smoking and lung haemorrhage in glomerulonephritis caused by antibodies to glomerular basement membrane. Lancet 1983;ii:1390-3.

7 Yamamoto $\mathrm{T}$, Wilson CB. Binding of anti-basement membrane antibody to alveolar basement membrane after intratracheal gasoline instillation in rabbits. Am J Patho 1987;126:497-505

8 Rees AJ, Peters DK, Composton DAS, Batchelor JR. Strong association between HLA-DRW 2 and antibody mediated Goodpasture's syndrome. Lancet 1978; i:966-8.

9 Johnson JP, Moore J, Austin HA, Balow JE, Antonovych TT, Wilson CB. Therapy of anti-glomerular basement membrane antibody disease: analysis of prognostic significance of clinical, pathologic and treatment factors. Medicine (Baltimore) 1985;64:219-27.

10 Savage COS, Pusey CD, Bowman C, Rees AJ, Lockwood CM. Antiglomerular basement membrane antibody mediated disease in British Isles 1980-4. Br J Med 1986;292:301-4.
Department of Internal Medicine J W Cohen Tervaert C G M Kallenberg

Department of Pathology J D Elema

University Hospital, 9713 EZ Groningen

Central Laboratory of the Blood Transfusion Service, Amsterdam, The Netherlands R Goldschmeding A E G Kr von dem Borne

Reprint requests to: Dr Cohen Tervaert.

Accepted 20 June 1990

\section{Antimyeloperoxidase antibodies in the Churg-Strauss syndrome}

Jan Willem Cohen Tervaert, Roel Goldschmeding, Job D Elema, Albert E G Kr von dem Borne, Cees G M Kallenberg

\begin{abstract}
Antibodies to myeloperoxidase were detected in the serum of three patients with the Churg-Strauss syndrome.

The Churg-Strauss syndrome, a rare multisystem disorder thought to be related to the systemic necrotising vasculitides, ${ }^{1}$ is characterised by hypereosinophilia, systemic vasculitis, asthma, and allergic rhinitis. ${ }^{22}$ Extravascular granulomas are frequently found but are absent in many cases. ${ }^{2}$

Antineutrophil cytoplasmic autoantibodies
\end{abstract}

Thorax 1991;46:70-71

(ANCA or ACPA) have been described recently in patients with Wegener's granulomatosis and microscopic polyarteritis. ${ }^{3}$ These antibodies are directed against a $29 \mathrm{kD}$ glycoprotein with serine protease activity derived from the azurophil granules of the neutrophil, ${ }^{5-8}$ probably proteinase- $3 .^{8-10} \mathrm{~A}$ characteristic granular pattern of staining of the cytoplasm of ethanol fixed granulocytes occurs (c-ANCA). Other staining patterns, however, have also been recognised-in particular, a perinuclear pattern. It has been shown that a substantial number of serum samples producing a perinuclear pattern have antibodies to human leucocyte elastase and/or myeloperoxidase, both lysosomal enzymes. ${ }^{11-13}$ In this report we describe the occurrence of myeloperoxidase ANCA in three consecutive patients with the Churg-Strauss syndrome.

\section{Case reports}

PATIENT 1

A 24 year old man presented in 1984 with asthma, rhinitis, and loss of weight. Treatment was started with corticosteroids. While the dose was being reduced severe dyspnoea developed followed by arthralgia, myalgia, episcleritis, fever, and mononeuritis multi- 
plex. Peripheral blood eosinophilia $(2.0 \times$ $\left.10^{9} / \mathrm{l}\right)$ and increased serum $\mathrm{IgE}(1695 \mathrm{IU} / \mathrm{ml})$ were found. Visceral angiography disclosed no abnormalities but a muscle biopsy showed necrotising arteritis with many giant cells. Treatment with high dose corticosteroids was started and cyclophosphamide was added after four weeks because of progression of the disease. Remission was obtained.

\section{PATIENT 2}

A 58 year old man presented in 1986 with asthma. In 1988 he was admitted to hospital because of dyspnoea, rhinitis, sinusitis, and episcleritis. He was treated with corticosteroids and while the dose was being reduced he developed myalgia, weight loss, fever, pulmonary infiltrates, pericarditis, and mononeuritis multiplex. Peripheral blood eosinophilia $\left(12.7 \times 10^{9} / 1\right)$ and increased serum $\operatorname{IgE}$ $(822 \mathrm{IU} / \mathrm{ml})$ were detected. Muscle biopsy showed necrotising arteritis with many eosinophils. He was treated with high dose corticosteroids and plasmapheresis and went into remission.

\section{PATIENT 3}

A 39 year old man presented in 1988 with asthma and rhinitis. Subsequently he developed weight loss, fever, and mononeuritis multiplex. He had peripheral blood eosinophilia $\left(9 \cdot 1 \times 10^{9} / 1\right)$ and increased serum IgE $(1620 \mathrm{IU} / \mathrm{ml})$. A muscle biopsy specimen was normal. In 1989 treatment with high dose corticosteroids was started. One month later paralytic ileus developed and bowel perforation was found at laparotomy. Histological examination disclosed necrotising arteritis with many eosinophils and extravascular granulomas. Remission was obtained after the start of cyclophosphamide treatment.

\section{Methods}

Anticytoplasmic antibodies were detected by indirect immunofluorescence. ${ }^{3}$ Antibodies to myeloperoxidase were detected by an enzyme linked immunosorbent assay (ELISA), in which a mouse monoclonal antibody to myeloperoxidase was the capture antibody and an extract of azurophilic granules from normal human granulocytes the antigen. ${ }^{13}$ Autoantibodies to the $29 \mathrm{kD}$ ANCA antigen or to elastase were detected by an assay identical to the ELISA method used for antimyeloperoxidase antibodies except that monoclonal antibodies either to the $29 \mathrm{kD}$ ANCA antigen or to elastase were used. ${ }^{13}$

\section{Results}

Serum from all three patients, obtained at the time of diagnosis, produced a perinuclear staining pattern with indirect immunofluorescence. In all three cases antimyeloperoxidase antibodies were found in the serum; antibodies to elastase or to the $29 \mathrm{kD}$ ANCA antigen were not detected.

\section{Discussion}

Recently c-ANCA were found in one patient with the Churg-Strauss syndrome. ${ }^{14}$ All our three patients had antimyeloperoxidase antibodies. These have been reported in patients with crescentic glomerulonephritis, either idiopathic or associated with vasculitis, ${ }^{121315}$ and in limited Wegener's granulomatosis, ${ }^{16}$ but not in other forms of glomerulonephritis, systemic lupus erythematosus, tuberculosis, or sarcoidosis, ${ }^{12} 13$ though one patient with this last disorder was weakly positive for antimyeloperoxidase antibodies. The finding of either antimyeloperoxidase antibodies or c-ANCA in patients with the Churg-Strauss syndrome places this disorder within the group of vasculitides, in which microscopic polyarteritis and Wegener's granulomatosis also occur.

1 Fauci AS, Leavitt RY. Vasculitis. In: McCarty DJ, ed. Arthritis and allied conditions. 11th ed. Philadelphia: Lea and Febiger, 1989:1166-88.

2 Lanham JG, Elkon KB, Pusey CD, Hughes GRV. Systemic vasculitis with asthma and eosinophilia: a clinical approach to the Churg-Strauss syndrome. Medicine (Baltimore) 1984;63:65-81.

3 van der Woude FJ, Rasmussen N, Lobatto S, et al. Autoantibody against neutrophils and monocytes: tool for diagnosis and marker of disease activity in Wegener's granulomatosis. Lancet 1985; i:425-9.

4 Specks V, DeRemee RA. Significance of antibodies to cytoplasmic components of neutrophils [editorial]. Thorax 1989;44:369-70.

5 Goldschmeding R, Tetteroo PAT, von dem Borne AEGKr, Kallenberg CGM. Anti-neutrophil-cytoplasm antibodies in Wegener's granulomatosis are not directed against alkaline phosphatase [letter]. Lancet 1987;i:1489.

6 Cohen Tervaert JW, Goldschmeding R, Hené RJ, Kallenberg CGM. Neutrophil cytoplasmic autoantibodies and Wegener's granulomatosis [letter]. Lancet 1989;i:270.

7 Harrison DJ, Kharbanda R. Autoantibodies to neutrophil cytoplasmic antigens in systemic vasculitis have the same target specificity. $J$ Pathol 1989;158:233-8.

8 Goldschmeding R, van der Schoot CE, ten Bokkel Huinink $\mathrm{D}$, et al. Wegener's granulomatosis autoantibodies identify a novel DFP-binding protein in the lysosomes of normal human neutrophils. J Clin Invest 1989;84: 1577-87.

9 Niles JL, McCluskey RT, Ahmad MF, Amin Arnaout M. Wegener's granulomatosis autoantigen is a novel neutrophil serine proteinase. Blood 1989;74:1888-93.

10 Lüdemann J, Utecht B, Gross WL. Anti-neutrophil cytoplasm antibodies in Wegener's granulomatosis recognize an elastinolytic enzyme. $J \operatorname{Exp}$ Med 1990;171:357-62.

11 Goldschmeding R, van der Schoot CE, Cohen Tervaert JW, Mason DY, von dem Borne AEGKr, Kallenberg CGM. Autoantibodies against myeloid lysosomal enzymes: novel class of autoantibodies associated with vasculitic syndromes [abstract]. Kidney Int 1988;34:558-9.

12 Falk RJ, Jennette JC. Anti-neutrophil cytoplasmic antibodies with specificity for myeloperoxidase in patients with systemic vsculitis and idiopathic necrotizing and crescentic glomerulonephritis. $N$ Engl J Med 1988; 318:1651-7.

13 Cohen Tervaert JW, Goldschmeding R, Elema JD, et al. Autoantibodies against myeloid lysosomal enzymes in crescentic glomerulonephritis. Kidney Int 1990;37 799-806

14 Harrison DJ, Simpson R, Kharbanda R, Abernethy VE, Nimmo G. Antibodies to neutrophil cytoplasmic antigens in Wegener's granulomatosis and other conditions. Thorax 1989;44:373-7.

15 Jennette JC, Wilkman AS, Falk RJ. Anti-neutrophil cytoplasmic autoantibody associated glomerulonephritis and vasculitis. Am J Pathol 1989;135:921-30.

16 Gans ROB, Goldschmeding R, Donker AJM, et al. Neutrophil cytoplasmic autoantibodies and Wegener's granulomatosis [letter]. Lancet 1989;i:269-70. 